\title{
Effects of shade level and microenvironment on vegetative growth, physiological and biochemical characteristics of transplanted cucumber (Cucumis sativus)
}

\author{
Wael M. Semida*, Mohamed S. Ammar and Nevein A. El-Sawah \\ Department of Horticulture, Faculty of Agriculture, Fayoum University, 63514-Fayoum, EGYPT \\ *Corresponding author's E-mail: wms00@fayoum.edu.eg
}

\section{ARTICLE HISTORY}

Received: 30 September 2017

Revised received: 05 October 2017

Accepted: 28 November 2017

Keywords

Cucumber transplants

Dehydration tolerance

Microenvironment

Shading nets

\begin{abstract}
Growing vegetables through transplantation under black shade nets is currently becoming popular to provide protection from high intensities of light and high temperatures. This study evaluated the effects of shade level on microenvironment, vegetative growth, photosynthetic pigments, chlorophyll $a$ fluorescence, osmoprotectants, plant water status and leaf mineral nutrients of greenhouse-grown summer cucumber transplants at $25 \%, 50 \%, 63 \%$, and $75 \%$ shade levels. Solar radiation and temperature decreased with increased shading levels. Average daily temperatures were approximately decreased by $1.5{ }^{\circ} \mathrm{C}$ under $75 \%$ shade nets compared to the $25 \%$ shade nets. Vegetative growth characteristics, photosynthetic pigments, chlorophyll $a$ fluorescence $\left(F_{v} / F_{m}, F_{v} / F_{0}\right.$, and PI), dehydration tolerance and Leaf N, P and K concentrations increased when shade level increased. Chlorophyll $a$ fluorescence $\left(F_{v} / F_{m}, F_{v} / F_{0}\right.$, and PI) reduced with the increase of solar radiation levels. Also, clear decreases in free proline, soluble sugars and total free amino acids in both experiments with increased shade level have been observed. Additionally, relative water content (RWC), membrane stability index (MSI) and electrolyte leakage (EL) of cucumber transplants were significantly affected in both experiments by shade level. Moreover Shade level affected leaf mineral nutrient but the effect differed among nutrients concentration. This study concluded that, nets with higher shading levels (63 and/or $75 \%$ ) are a potential alternative to alleviate photo-inhibition and heat stress in cucumber transplants production.
\end{abstract}

(C2017 Agriculture and Environmental Science Academy

Citation of this article: Semida, W.M., Ammar, M.S. and El-Sawah, N.A. (2017). Effects of shade level and microenvironment on vegetative growth, physiological and biochemical characteristics of transplanted cucumber (Cucumis sativus). Archives of Agriculture and Environmental Science, 2(4): 361-368, DOI: 10.26832/24566632.2017.020421

\section{INTRODUCTION}

In traditional vegetable-producing regions, transplanting is a wellknown technique used especially for higher valued vegetables to improve growth performance and productivity. However, young vegetable seedlings transplants in arid and/or semiarid regions are often exposed to environmental stresses of various levels depending on the season, such as drought and heat stresses (Shinohara and Leskovar, 2014).

In greenhouse system there are many effective growth factors such as temperature, relative humidity, light and solar radiation. Of all the climatic factors affecting vegetable production, temperature is considered as one of the most important factors. Global temperature has increased by $0.3-0.6^{\circ} \mathrm{C}$ since the late $19^{\text {th }}$ century and by $0.2-0.3^{\circ} \mathrm{C}$ over the last 40 years. In the last 140 years, the 1990 s was the warmest period (Jones and Briffa, 1992). Temperature affects growth and development of vegetables in terms of seed germination, development of economic parts, flowering, pollination, fruit set, quality of produce, seed production, seed storage, seed dormancy and occurrence of disease and pests. Growth and development of most vegetable crops are adversely affected at temperatures less than $5{ }^{\circ} \mathrm{C}$. Growth normally increases with increasing temperatures up to $40{ }^{\circ} \mathrm{C}$, and thereafter it decreases drastically (Taiz and Zeiger, 2010).

Moreover, light is the most important environmental parameters that represent the climate of green house, short wave lengths ultraviolet rays, to low energy, long wave length radio waves. Plant life ultimately depends on energy derived from the sun light, and photosynthesis is the only biological important process that can harvest this energy in the form of carbohydrates. In addition to photosynthesis, there are many other aspects of plant growth most affected by light: chlorophyll synthesis, photoperiod, photomorphogensis, phototropism and photo inhibition (Taiz and Zeiger, 2010).

Low-cost protected cultivation, such as plastic tunnels and net houses, has the potential to reduce different biotic and abiotic stresses, which affect productivity and quality (Ilić et al., 2015). Netting, is frequently used to protect transplants and other commercial crops from excessive solar radiation, to improve the thermal climate sheltering from wind and hail, and for exclusion of birds and insecttransmitted viral diseases (Shahak, 2008; Kong et al., 2013; Ilić and Fallik, 2017). Significant amount of work has been done on the effect of shading material including shade clothes with varying degree of shading, colored shade nets, and partially shade screens ( $\mathrm{Li}$ et al., 2000; Buthelezi et al., 2016; Chang et al., 2016; Sivakumar et al., 2017) to reduce the photo-inhibition or/and high temperature caused by light. Moderate shading could improve the photosynthesis and thereby increase yields and quality through improved carbohydrate supply and efficient water use (Shahak et al., 2008). Shading effect of black shade nets can lower the inner temperature under the nets with a higher shade factor leading to decreased radiation exposure. The incident of radiation from the sun is partially reflected or ab- 
sorbed by the shade nets. The part of the radiation that was not reflected or absorbed by the shade nets is transmitted via the nets (Al-Helal and Abdel-Ghany, 2012). However, a negative correlation exists between weight or density of the shade nets and the light transmittance. Lower density of shading gives greater total light transmittance through the nets (Castellano et al., 2008). Therefore, the objective of the current study was to determine how black shade nets with different degrees of shading $(25 \%, 50 \%, 63 \%$ and $75 \%$ shading with a black nets) could influence growth and quality parameters of cucumber transplants.

\section{MATERIALS AND METHODS}

Layout and experimentation: Experiments were conducted at Demo farm, faculty of agriculture, Fayoum, Egypt located at latitude of $29.18^{\circ} \mathrm{N}$ and longitude angle of $30.3^{\circ}$. The experiments aimed to evaluate the response of summer cucumber transplants, hybrid Bahi ${ }^{\circledR}$, to different degrees of shading nets. Four black shading nets; Shade $75 \%$, Shade $63 \%$, Shade 50 $\%$, and Shade $25 \%$, according to the manufacturer, were used. Two experiments were conducted during May and August 2014. The experiments were set out as two blocks in which four shading covers were randomly allocated on eight mini tunnels measuring ( $2 \mathrm{~m}$ width $\mathrm{X} 2 \mathrm{~m}$ height $\mathrm{X} 3 \mathrm{~m}$ length). Seeds of cucumber were sown in foam trays ( 84 cells) on May $17^{\text {th }}$ and August $15^{\text {th }} 2014$, where three trays were allocated within each tunnel. Seed germination media contained peat moss: vermiculite ( $1: 1$ by volume). Transplants were destructively harvested for morphological, physiological and biochemical measurements $30 \mathrm{~d}$ after sowing.

Observation: Average daily temperature in each tunnel was measured using Tenmars data loggers (TM305-Temperature/ RH Data Logger Neihu, Taiwan). The temperature was measured every $10 \mathrm{~min}$ and then daily average temperature was computed. Total radiation in each tunnel was measured using Data Acquisition system (Tenmars-Solar power meterTM206, Neihu, Taiwan). Radiation in each tunnel was measured three days a week from (09.00 am to $04.00 \mathrm{pm})$ every $1 \mathrm{~h}$ and a daily average were computed.

120 destructive transplants after 30 days of sowing were randomly chosen from each treatment (sixty plants per mini tunnel, twenty plants from each tray). Growth measurements included leaf number, leaf area, leaf thickness, stem diameter, shoot length, as well as fresh and dry leaf weights $(\mathrm{g})$ were conducted at destructive harvest. Dry weight measurements were carried out after drying to constant weight in a ventilated oven at $70^{\circ} \mathrm{C}$. Stem diameter was measured using (Electronic Digital Calipers, Precision Gold, China). Leaf thickness was measured using (Digital Thickness Gauge, Maplin Electronics, UK). Leaf areas were measured using leaf area - leaf weight relationship as illustrated by Wallace and Munger (1965) with some modifications as described by Semida et al. (2017). Leaf surface was thoroughly washed in running tap water followed by washing with double distilled water, thereafter 10-20 leaf discs $\left(10-20 \mathrm{~cm}^{2}\right)$ were dried in an oven at $85^{\circ} \mathrm{C}$ for $24 \mathrm{~h}$ to get discs dry weight (DDW). Total leaf area plant ${ }^{-1}$ was calculated using the following formula:

$$
\text { Total leaf area plant }{ }^{-1}=\left[\frac{\mathrm{LDW}}{\mathrm{DDW}}\right] \times \mathrm{DA}
$$

Where, LDW is the total leaf dry weight $(\mathrm{g})$, DDW is the discs dry weight and DA is the discs area. Leaf chlorophyll A, $\mathrm{B}$, and carotenoid concentrations ( $\mathrm{mg} \mathrm{g}^{-1}$ fresh weight) were measured and calculated according to Arnon (1949). Membrane stability index (MSI), relative water content (RWC) and electrolyte leakage (EL \%) were determined as described by Rady (2011), Hayat et al. (2007) and Sullivan et al. (1979), respectively. Leaf N, P and K contents were determined according to Hafez and Mikkelsen (1981), Jackson (2005) and Page et al. (1982), respectively.

Free proline and Total soluble sugars (TSS) was extracted and measured (in mg per $\mathrm{g}$ of leaf DW) in dried leaf tissue as described by Bates et al. (1973) and Irigoyen et al. (1992), respectively. Total free amino acids were determined as illustrated by Dubey and Rani (1989) with some modifications. $0.2 \mathrm{~g}$ dried leaf tissue was extracted in $10 \mathrm{ml}$ of $80 \%(\mathrm{v} /$ v) ethanol and filtered. Five $\mathrm{ml}$ of ninhydrin reagent was added to a $0.1 \mathrm{ml}$ aliquot of the extract, shaken vigorously, and heated in a boiling water bath for 10 min. After cooling, the absorbance was recorded at $570 \mathrm{~nm}$.

Chlorophyll $a$ fluorescence was measured using a portable fluorometer (Handy PEA, Hansatech Instruments Ltd, Kings Lynn, UK). One leaf (the same age) at solar noon was chosen per plant. Maximum quantum yield of PS II $F_{v} / F_{m}$ was calculated using the formula; $F_{v} / F_{m}=\left(F_{m}-F_{0}\right) / F_{m}$ (Maxwell and Johnson, 2000). $F_{v} / F_{0}$ reflects the efficiency of electron donation to the PSII RCs and the rate of photosynthetic quantum conversion at PSII RCs. $F_{v} / F_{0}$ was calculated using the formula; $F_{v} / F_{0}=\left(F_{m}-F_{0}\right) / F_{0}$ (Spoustová et al., 2013). Performance index (PI) of photosynthesis based on the equal absorption $\left(\mathrm{PI}_{\mathrm{ABS}}\right)$ was calculated as reported by Clark et al. (2000).

Statistical analysis: All data were subjected to analysis of variance (ANOVA) procedures in Genstat statistical package (version 11) (VSN International Ltd, Oxford, UK). Difference between means was compared using least significant difference test (LSD) at 5\% level.

\section{RESULTS AND DISCUSSION}

Microenvironment: The solar radiation transmission, and mean solar radiation during two growing seasons in 2014 are shown in Figures 1 and 2. Mean daily air temperature and average mean temperature are shown in Figure 3 and 4. Results showed that solar radiation and temperature have been strongly affected by shading level. Solar radiation and temperature decreased with increased shading levels. Of the tested shading nets, $25 \%$ shade exhibited the highest light transmission compared to other covers with higher shading levels (50, 63 , and $75 \%$, respectively). Temperature has been strongly affected by shading level. The $25 \%$ shade cover appears to give constantly highest average daily temperature, while the $75 \%$ shade nets gave the lowest temperature, and other shading net treatments showed intermediate temperature characteristics. The average daily temperatures fewer than $75 \%$ shade nets were approximately decreased by $1.5^{\circ} \mathrm{C}$, compared to the 25\% shade nets (Figures 3 and 4 ).

Vegetative growth and physiological characteristics: During this investigation, number of leaves per transplant, leaf area, shoot length, stem diameter, shoots FW, and Shoot DW increased with increased shade level, whereas leaf thickness was not significantly different among shade levels. Number of leaves per transplant grown under $75 \%, 63 \%$ and $50 \%$ of shading were significantly $(\mathrm{P}=0.026$ and $\mathrm{P}=0.002$ for the experiments 1 and 2, respectively) higher as compared to the $25 \%$ shades in both experiments. The average of leaves area was significantly $(\mathrm{P}<0.001)$ higher under $75 \%$ and $63 \%$ shade followed by other shading levels (50 and/or $25 \%$ ) in both experiments (Table 1). Similar trends were observed, in both experiments, for shoot length, stem diameter, shoot FW, and Shoot DW (Table 2). Shoot length and shoot fresh and dry weights were highest $(\mathrm{P}<0.001)$ for shade $75 \%$ followed 
by shade $63 \%$, shade $50 \%$, and shade $25 \%$. Stem diameter was highest $(\mathrm{P}=0.02$ and $\mathrm{P}<0.001$ for the experiments 1 and 2 , respectively) for shade $75 \%$ followed by shade $63 \%$, shade $50 \%$, and shade $25 \%$.

In the present study, chlorophyll a, chlorophyll $\mathrm{b}$, total chlorophyll, carotenoids, and chlorophyll a fluorescence $\left(\mathrm{F}_{\mathrm{v}} / \mathrm{F}_{\mathrm{m}}, \mathrm{F}_{\mathrm{v}} /\right.$ $\mathrm{F}_{0}$, and PI) increased, in both experiments, with increased shade level (Tables 3 and 4). Chlorophyll a, chlorophyll b, total chlorophyll was significantly higher for shade $75 \%$ and/ or shade $63 \%$ in both experiments, followed by shade $50 \%$, and shade $25 \%$. Total chlorophyll was highest $(\mathrm{P}=0.02$ and $\mathrm{P} \leq 0.001$ and for experiments 1 and 2, respectively) for shade $75 \%$ followed by shade $63 \%$, shade $50 \%$, and shade $25 \%$. Similar trends were observed, in both experiments, for carotenoids (Table 3). Carotenoids were highest $(\mathrm{P} \leq 0.01)$, in both experiments, for shade $75 \%$ followed by shade $63 \%$, shade $50 \%$, and shade $25 \%$.

Chlorophyll $a$ fluorescence $\left(F_{v} / F_{m}, F_{v} / F_{0}\right.$, and PI) reduced with the increase of solar radiation levels (Table 4). Significant differences were observed in $F_{v} / F_{m}$, and $F_{v} / F_{0}$ of plants grown under shade $75 \%$ and/or shade $63 \%$ compared to those plants grown under shade $50 \%$, and shade $25 \%$. Fv/Fm and $F v / F 0$ were highest $(P \leq 0.001)$ in both experiments for shade $75 \%$ followed by shade $63 \%$, shade $50 \%$, and shade $25 \%$. Similarly, plants grown under shade $75 \%$ and/or shade $63 \%$ significantly $(P<0.001)$ resulted in higher PI than under shade $50 \%$, and shade $25 \%$ (Table 4 ).

During the present study, free proline, soluble sugars, and total free amino acids decreased, in both experiments, with increased shade level (Table 5). Significant differences were observed in in the concentrations of free proline of plants grown under shade $75 \%$, shade $63 \%$, and shade $50 \%$ compared to those plants grown under shade $25 \%$. Concentrations of free proline were highest $(P \leq 0.001)$ in both experiments for shade $25 \%$ followed by shade $50 \%$, shade $63 \%$, and shade $75 \%$. Similar trends were observed, in both experiments, for soluble sugars and total free amino acids (Table 5). Soluble sugars were highest for shade $25 \%$ followed by shade $50 \%$, shade $63 \%$, and shade $75 \%$. Total free amino acids was significantly highest $(P=0.039$ and $P=0.005$ for experiments 1 and 2 , respectively), in both experiments, for shade $25 \%$ followed by shade $50 \%$, shade $63 \%$, and shade $75 \%$.

Plant water status and leaf mineral nutrients: Data shown in Table 6 reveal that relative water content (RWC), membrane stability index (MSI), and electrolyte leakage (EL) of cucumber transplants were significantly affected, in both experiments, by shade level. Cucumber transplants grown under shade $75 \%$ and/or shade $63 \%$ revealed a significant increase in dehydration tolerance in terms of increased RWC and MSI and reduced EL compared to those plants grown under shade $50 \%$, and shade $25 \% \%$. RWC was significantly highest $(\mathrm{P}=0.02$ and $\mathrm{P} \leq 0.001$ for exp. 1 and 2 respectively), in both experiments, for shade $75 \%$ followed by shade $63 \%$, shade $50 \%$, and shade $25 \%$. MSI was also significantly highest $(\mathrm{P} \leq 0.001$ and $\mathrm{P}=0.012$ for the experiments 1 and 2 , respectively), in both experiments, for shade $75 \%$ followed by shade $63 \%$, shade $50 \%$, and shade $25 \%$. In contrast, EL were highest $(\mathrm{P} \leq 0.001)$ in both experiments for shade $25 \%$ followed by shade $50 \%$, shade $63 \%$, and shade $75 \%$.

Shade level affected leaf mineral nutrient concentration but the effect differed among nutrients. Leaf N, P and K concentrations increased with shade level (Table 7). Concentrations of leaf $\mathrm{N}, \mathrm{P}$ and $\mathrm{K}$ were significantly highest in both experiments for shade $75 \%$ followed by shade $63 \%$, shade $50 \%$, and shade $25 \%$. Leaf $\mathrm{N}$ concentration was significantly highest
( $P \leq 0.001$ and $P=0.007$ for the experiments 1 and 2 , respectively), in both experiments, for shade $75 \%$ followed by shade $63 \%$, shade $50 \%$ and shade $25 \%$. P concentration was also significantly highest $(P=0.004$ and $P \leq 0.001$ for the experiments 1 and 2 , respectively), in both experiments, for shade $75 \%$ followed by shade $63 \%$, shade $50 \%$, and shade $25 \%$. Similarly, $\mathrm{K}$ were highest $(P \leq 0.001)$ in both experiments for shade $25 \%$ followed by shade $50 \%$, shade $63 \%$, and shade $75 \%$.

Shading nets are intended to reduce solar radiation in order to reduce heat stress especially during summer inside greenhouses. Significant amount of work has been done on the effect of shading materials including shade clothes with varying degree of shading, shade nets, and partially shad screens (Shahak et al., 2008; Stamps, 2009; Semida et al., 2013; Ilić and Fallik, 2017) to reduce the photo inhibition and/or high temperature caused by light. Our studies show that solar radiation and temperature have been strongly affected by shading level. Over the two repeats of summer cucumber experiments in which transplants were grown under different shade levels, solar radiation decreased with increased shading levels (Figures 1 and 2). Also, temperature has been strongly affected by shading level, but the effect differed among experiments. Over the two repeats of summer cucumber, temperature decreased with increased shading levels (Figures 3 and 4). Our results are consistent with previous reports that show that shading reduces solar radiation and air temperature (Kittas et al., 2009; Semida, 2011; Díaz-Pérez, 2013). A 30\% black shading cover was found to reduce solar radiation and wind speed but did not significantly alter maximum daily air temperature as compared with open field conditions (Möller and Assouline, 2007). Heavy shading (75\%) on basil, strongly reduce photosynthesis rate and, effectively reduce leaf temperature when air temperature was less than $30^{\circ} \mathrm{C}$ (Chang et al., 2008). Light quality modification by colored shade nets efficiently decreases temperature compared with black shading. This might be due to the higher content of scattered/ diffuse light (Ilić and Fallik, 2017). The reduction in air temperature during the summer experiments under higher shade levels could be attributed to the light diffusive characteristics and the shaded environment of the black nets. A significant reduction in air temperature due to shading was also reported in a greenhouse study on strawberry, tomato, and sweet pepper even though a different type of shading was used compared to the current study (Aberkani et al., 2010; Semida, 2011).

Overall this study showed that vegetative growth characteristics i.e., leaves number, leaf area, shoot length, stem diameter, shoot FW, and shoot DW, increased when shade level increased (Tables 1 and 2). Under shade condition, plants undergo morphological changes to maximize light use. Modification of the light spectrum quality and quantity via black and/or colored shade nets can act as a physiological tool to modify the crop micro-climate and enhance plant growth and productivity (Ilić and Fallik, 2017). Plants adapted to shade have greater foliar surface and specific leaf area, thinner leaves, and taller stems compared with plants adapted to strong light (Larcher, 2003). Our results agree with studies showing that shaded bell peppers and tomato plants have longer internodes, larger leaves, greater whole-plant leaf area, and thinner leaves (Kittas et al., 2009; Díaz-Pérez, 2013). Results are also consistent with a cucumber and tomato study, in which shaded plants grow taller than unshaded plants, and produce a greater average internode length (El-Abd et al., 1994). Plants grown in the shade tend to have a larger leaf area because cells expand more under low light intensities in 
order to receive light for photosynthesis (Tinyane, 2013).

At high sunlight intensities, chlorophyll degradation rate in plant leaves is higher than the synthesis rate, leading to a decrease in chlorophyll concentration as a result of chloroplast formation inhibition. Accordingly, shade leaves in comparison with sun leaves tend to show higher chlorophyll concentrations per unit of leaf weight (Fu et al., 2012). Although the formation of carotenoids in mature fruits does not require induction by light, shaded fruits have lower content of carotenoids (Dorais and Papadopoulos, 2001). The carotenoid content was lowest in plants from open fields and highest in plants covered by black nets (Ilic et al., 2017). This study clearly showed that Chlorophyll $a$, chlorophyll $b$, total chlorophyll, and carotenoids increased with increased shade level (Table 3). Although shade-grown plants are not directly exposed to sunlight, they produce additional chlorophyll $a$ and $b$ to capture diffuse radiation to produce the carbohydrates needed for the plant to grow, as supported by the results of Beneragama and Goto (2010). Shaded lettuce leaves showed higher total chlorophyll (chlorophyll $a$ and $b$ ) content than leaves from unshaded control plants (Ilic et al., 2017). Minimal chlorophyll fluorescence $\left(F_{0}\right)$ has been reported to increase with the increase of the irradiance. Reduction in the maximum photochemical efficiency of PSII $(F v / F m)$ under excessive photosynthetic photon flux density (PPFD) is a widely reported phenomenon in plants (Parker and Mohammed, 2000). $F v / F m$ reduced with the increase of photosynthetic photon flux density (PPFD) levels (Pires et al., 2011). Other studies have found $\mathrm{Fv} / \mathrm{Fm}$ to be similar and occasionally higher in shaded plants (Groninger et al., 1996). These results are consistent with the result of the current study (Table 4), indicating that shading increases chlorophyll $a$ fluorescence $\left(F_{v} / F_{m}, F_{v} / F_{0}\right.$, and PI), which can serve as an indicator of the plant's photosynthetic efficiency.

When plants are exposed to the direct sunlight irradiance, they could induce some protective mechanisms such as the increases in proline, sugars, and the activity of antioxidant enzymes as reported by Prochazkova et al. (2001). We have observed clear decreases in free proline, soluble sugars, and total free amino acids with increased shade level (Table 5). Sugar accumulation in vegetables is mainly affected by light intensity and temperature. Consequently, exposing fruit to higher temperatures, especially during ripening, leads to an increase in the total soluble solids content (SSC), mainly due to an increase in carbohydrate biosynthetic enzyme activity and increased transpiration (Guillén et al., 2007). Pepper fruits grown in plastic shad nets had significantly lower TSS content when compared with unshaded fruits (Ilic et al., 2017). Conversely, lettuce grown under pearl (and yellow shading nets showed the highest soluble sugar content (Ntsoane et al., 2016). The higher blue light transmittance during the production of tomato under pearl shading nets showed higher SSC/TA ratios (Elad et al., 2007).

Our studies show that cucumber transplants grown under higher shade levels (63 and $75 \%$ ) showed a significant increase in dehydration tolerance in terms of increased RWC and MSI and reduced EL compared to those plants grown under lower shade and/or unshaded conditions (Table 6). As a measure of plant water status, RWC reflects the metabolic activity in plant tissues, and used as a most meaningful index to identify the legumes with contrasting differences in dehydration tolerance (Sinclair and Ludlow, 1986). Moderate shade alleviated the drought stress of $P$. cathayana not only by improving the leaf RWC but also by maintaining the positive carbon balance (Huang et al., 2009).

Over the different repeats of the experiments in which transplants were grown under different shade levels, lower shade conditions invariably caused significant reductions in leaf mineral nutrient i.e., N, P, and K (Table 7). This was consistent with the report by El-Gizawy et al. (1992) who showed that tissue $\mathrm{N}, \mathrm{P}$, and $\mathrm{K}$ levels were increased with increasing shading level. Liu et al. (2003) also studied the effect of different shading levels on tomato leaves nutrient contents, especially $\mathrm{N}, \mathrm{P}$ and $\mathrm{K}$. their results showed that shading had no effect on total leaf $\mathrm{N}, \mathrm{P}$ and $\mathrm{K}$ contents at the early and peak flowering stages. However, leaf N, P and K contents of $40 \%$ shaded plants at the later flowering stage were significantly increased. There were no difference in leaf $\mathrm{N}$ and $\mathrm{K}$ contents between $40 \%$ and $75 \%$ shading treatments.

Table 1. Effect of shading on number of leaves, leaves area and leaf thickness of cucumber transplants during the summer season.

\begin{tabular}{|c|c|c|c|}
\hline Treatment & Number of leaves & Leaves area $\left(\mathrm{dm}^{2}\right)$ & Leaf thickness \\
\hline \multicolumn{4}{|c|}{ Summer cucumber (Experiment 1) } \\
\hline Shade $75 \%$ & $4.85 \mathrm{a} \pm 0.06$ & $6.87 \mathrm{a} \pm 0.43$ & $0.52 \mathrm{a} \pm 0.02$ \\
\hline Shade $63 \%$ & $4.73 \mathrm{ab} \pm 0.07$ & $5.5 \mathrm{~b} \pm 0.23$ & $0.48 \mathrm{a} \pm 0.01$ \\
\hline Shade $50 \%$ & $4.73 \mathrm{ab} \pm 0.07$ & $3.6 \mathrm{c} \pm 0.13$ & $0.50 \mathrm{a} \pm 0.02$ \\
\hline Shade $25 \%$ & $4.55 \mathrm{~b} \pm 0.08$ & $3.8 \mathrm{c} \pm 0.16$ & $0.51 \mathrm{a} \pm 0.04$ \\
\hline \multicolumn{4}{|c|}{ Summer cucumber (Experiment 2) } \\
\hline Shade $75 \%$ & $4.90 \mathrm{a} \pm 0.05$ & $6.94 \mathrm{a} \pm 0.43$ & $0.52 \mathrm{a} \pm 0.03$ \\
\hline Shade $63 \%$ & $4.88 \mathrm{a} \pm 0.05$ & $5.43 b \pm 0.23$ & $0.48 \mathrm{a} \pm 0.02$ \\
\hline Shade $50 \%$ & $4.85 \mathrm{a} \pm 0.06$ & $3.62 \mathrm{c} \pm 0.13$ & $0.51 \mathrm{a} \pm 0.02$ \\
\hline Shade $25 \%$ & $4.62 b \pm 0.14$ & $3.98 \mathrm{c} \pm 0.17$ & $0.41 \mathrm{a} \pm 0.02$ \\
\hline
\end{tabular}

Values are means \pm SE $(n=40)$. Mean values in each column followed by a different lower-case-letter are significantly different by Fisher's least-significant difference test (LSD) at $P \leq 0.05$.

Table 2. Effect of shading on shoot length, shoot fresh and dry weights and stem diameter of cucumber transplants during the summer season.

\begin{tabular}{|c|c|c|c|c|}
\hline Treatment & Shoot length (cm) & Shoot fresh weight (g) & Shoot dry weight (g) & Stem diameter $(\mathrm{mm})$ \\
\hline \multicolumn{5}{|c|}{ Summer cucumber (Experiment 1) } \\
\hline Shade $75 \%$ & $4.91 \mathrm{a} \pm 0.07$ & $2.10 \mathrm{a} \pm 0.04$ & $0.32 \mathrm{a} \pm 0.06$ & $4.30 \mathrm{a} \pm 0.01$ \\
\hline Shade $63 \%$ & $3.79 b \pm 0.06$ & $1.86 \mathrm{~b} \pm 0.04$ & $0.23 \mathrm{c} \pm 0.06$ & $4.26 \mathrm{a} \pm 0.00$ \\
\hline Shade $50 \%$ & $3.55 \mathrm{c} \pm 0.07$ & $1.77 \mathrm{bc} \pm 0.04$ & $0.25 \mathrm{~b} \pm 0.07$ & $4.15 \mathrm{a} \pm 0.01$ \\
\hline Shade $25 \%$ & $3.55 \mathrm{c} \pm 0.06$ & $1.69 \mathrm{c} \pm 0.05$ & $0.20 \mathrm{~d} \pm 0.07$ & $4.05 \mathrm{a} \pm 0.00$ \\
\hline \multicolumn{5}{|c|}{ Summer cucumber (Experiment 2) } \\
\hline Shade $75 \%$ & $5.58 \mathrm{a} \pm 0.12$ & $3.45 \mathrm{a} \pm 0.07$ & $0.20 \mathrm{a} \pm 0.00$ & $3.89 \mathrm{a} \pm 0.13$ \\
\hline Shade $63 \%$ & $4.31 \mathrm{~b} \pm 0.10$ & $3.20 \mathrm{~b} \pm 0.08$ & $0.18 \mathrm{~b} \pm 0.01$ & $3.97 \mathrm{a} \pm 0.07$ \\
\hline Shade $50 \%$ & $4.42 \mathrm{~b} \pm 0.14$ & $2.26 \mathrm{c} \pm 0.09$ & $0.18 \mathrm{~b} \pm 0.01$ & $3.86 \mathrm{a} \pm 0.11$ \\
\hline Shade $25 \%$ & $3.69 \mathrm{c} \pm 0.10$ & $2.13 \mathrm{c} \pm 0.06$ & $0.16 \mathrm{c} \pm 0.00$ & $2.78 \mathrm{~b} \pm 0.19$ \\
\hline
\end{tabular}

Values are means $\pm \mathrm{SE}(\mathrm{n}=40)$. Mean values in each column followed by a different lower-case-letter are significantly different by Fisher's least-significant difference test (LSD) at $P \leq 0.05$. 
Table 3. Effect of shading on chlorophyll $a$, chlorophyll $b$, total chlorophyll and carotenoids of cucumber transplants during the summer season.

\begin{tabular}{|c|c|c|c|c|}
\hline Treatment & Chlorophyll $a\left(\mathrm{mg} \mathrm{g}^{-1} \mathrm{FW}\right)$ & Chlorophyll $b$ (mg g $\left.{ }^{-1} \mathrm{FW}\right)$ & Total chlorophyll ( $\left.\mathrm{mg} \mathrm{g}^{-1} \mathrm{FW}\right)$ & Carotenoids ( $\left.\mathrm{mg} \mathrm{g}^{-1} \mathrm{FW}\right)$ \\
\hline \multicolumn{5}{|c|}{ Summer cucumber (Experiment 1) } \\
\hline Shade $75 \%$ & $0.66 \mathrm{a} \pm 0.02$ & $0.57 \mathrm{a} \pm 0.03$ & $5.40 \mathrm{a} \pm 0.22$ & $0.14 \mathrm{a} \pm 0.00$ \\
\hline Shade $63 \%$ & $0.67 \mathrm{a} \pm 0.04$ & $0.56 \mathrm{a} \pm 0.04$ & $5.58 \mathrm{a} \pm 0.45$ & $0.13 \mathrm{a} \pm 0.02$ \\
\hline Shade $50 \%$ & $0.56 \mathrm{~b} \pm 0.03$ & $0.44 \mathrm{~b} \pm 0.02$ & $5.03 \mathrm{a} \pm 0.30$ & $0.13 \mathrm{a} \pm 0.01$ \\
\hline Shade $25 \%$ & $0.59 \mathrm{ab} \pm 0.03$ & $0.50 \mathrm{ab} \pm 0.02$ & $4.73 b \pm 0.24$ & $0.10 \mathrm{~b} \pm 0.01$ \\
\hline \multicolumn{5}{|c|}{ Summer cucumber (Experiment 2) } \\
\hline Shade $75 \%$ & $0.69 \mathrm{a} \pm 0.03$ & $0.46 \mathrm{a} \pm 0.02$ & $4.61 \mathrm{a} \pm 0.18$ & $0.10 \mathrm{a} \pm 0.01$ \\
\hline Shade $63 \%$ & $0.61 \mathrm{ab} \pm 0.04$ & $0.40 \mathrm{ab} \pm 0.02$ & $4.22 \mathrm{a} \pm 0.23$ & $0.06 \mathrm{~b} \pm 0.00$ \\
\hline Shade $50 \%$ & $0.54 \mathrm{bc} \pm 0.02$ & $0.37 \mathrm{~b} \pm 0.04$ & $3.55 \mathrm{~b} \pm 0.18$ & $0.04 \mathrm{c} \pm 0.01$ \\
\hline Shade $25 \%$ & $0.50 \mathrm{c} \pm 0.03$ & $0.30 \mathrm{c} \pm 0.01$ & $3.21 \mathrm{~b} \pm 0.15$ & $0.04 \mathrm{c} \pm 0.00$ \\
\hline
\end{tabular}

Values are means \pm SE $(n=6)$. Mean values in each column followed by a different lower-case-letter are significantly different by Fisher's least-significant difference test (LSD) at $P \leq 0.05$.

Table 4. Effect of shading on chlorophyll $a$ fluorescence $\left(F_{v} / F_{m}, F_{v} / F_{0}\right.$, and PI) of cucumber transplants during the summer season.

\begin{tabular}{|c|c|c|c|}
\hline Treatment & $F_{v} / F_{m}$ & $F_{v} / F_{0}$ & PI \\
\hline \multicolumn{4}{|c|}{ Summer cucumber (Experiment 1) } \\
\hline Shade $75 \%$ & $0.81 \mathrm{a} \pm 0.00$ & $4.38 \mathrm{a} \pm 0.06$ & $4.20 \mathrm{a} \pm 0.22$ \\
\hline Shade $63 \%$ & $0.78 \mathrm{ab} \pm 0.01$ & $3.61 \mathrm{~b} \pm 0.23$ & $2.43 b \pm 0.23$ \\
\hline Shade $50 \%$ & $0.73 b \pm 0.03$ & $3.33 \mathrm{~b} \pm 0.38$ & $1.97 \mathrm{~b} \pm 0.22$ \\
\hline Shade $25 \%$ & $0.66 \mathrm{c} \pm 0.03$ & $2.04 \mathrm{c} \pm 0.28$ & $1.87 \mathrm{~b} \pm 0.51$ \\
\hline \multicolumn{4}{|c|}{ Summer cucumber (Experiment 2) } \\
\hline Shade $75 \%$ & $0.79 \mathrm{a} \pm 0.00$ & $3.74 \mathrm{ab} \pm 0.10$ & $2.52 \mathrm{ab} \pm 0.17$ \\
\hline Shade $63 \%$ & $0.79 \mathrm{a} \pm 0.00$ & $3.76 \mathrm{a} \pm 0.11$ & $2.54 \mathrm{a} \pm 0.26$ \\
\hline Shade $50 \%$ & $0.77 \mathrm{~b} \pm 0.01$ & $3.24 b \pm 0.14$ & $1.26 b c \pm 0.16$ \\
\hline Shade $25 \%$ & $0.75 c \pm 0.01$ & $2.42 \mathrm{c} \pm 0.27$ & $0.78 \mathrm{c} \pm 0.11$ \\
\hline
\end{tabular}

Values are means \pm SE $(n=10)$. Mean values in each column followed by a different lower-case-letter are significantly different by Fisher's least-significant difference test (LSD) at $P \leq 0.05$.

Table 5. Effect of shading on free proline, soluble sugars, and total free amino acids of cucumber transplants during the summer season.

\begin{tabular}{|c|c|c|c|}
\hline Treatment & Free proline ( $\left.\mathrm{mg} \mathrm{g}^{-1} \mathrm{DW}\right)$ & Soluble sugars ( $\left.\mathrm{mg} \mathrm{g}^{-1} \mathrm{DW}\right)$ & Total free amino acids $\left(\mathrm{mg} \mathrm{g}^{-1} \mathrm{DW}\right)$ \\
\hline \multicolumn{4}{|c|}{ Summer cucumber (Experiment 1) } \\
\hline Shade $75 \%$ & $0.26 \mathrm{~b} \pm 0.03$ & $0.978 \mathrm{~b} \pm 0.05$ & $0.0940 \mathrm{~b} \pm 0.01$ \\
\hline Shade $63 \%$ & $0.32 b \pm 0.02$ & $1.048 \mathrm{~b} \pm 0.11$ & $0.1240 \mathrm{~b} \pm 0.02$ \\
\hline Shade $50 \%$ & $0.35 \mathrm{~b} \pm 0.01$ & $1.096 \mathrm{~b} \pm 0.08$ & $0.1360 \mathrm{~b} \pm 0.02$ \\
\hline Shade $25 \%$ & $0.60 \mathrm{a} \pm 0.07$ & $1.316 \mathrm{a} \pm 0.03$ & $0.1840 \mathrm{a} \pm 0.03$ \\
\hline \multicolumn{4}{|c|}{$\begin{array}{l}\text { Summer cucumber (Experiment 2) } \\
\end{array}$} \\
\hline Shade $75 \%$ & $0.28 \mathrm{c} \pm 0.02$ & $1.48 \mathrm{a} \pm 0.15$ & $0.15 \mathrm{~b} \pm 0.02$ \\
\hline Shade $63 \%$ & $0.31 \mathrm{c} \pm 0.03$ & $1.54 \mathrm{a} \pm 0.26$ & $0.14 \mathrm{~b} \pm 0.01$ \\
\hline Shade $50 \%$ & $0.40 \mathrm{~b} \pm 0.02$ & $1.62 \mathrm{a} \pm 0.12$ & $0.16 \mathrm{~b} \pm 0.01$ \\
\hline Shade $25 \%$ & $0.57 \mathrm{a} \pm 0.02$ & $1.68 \mathrm{a} \pm 0.16$ & $0.21 \mathrm{a} \pm 0.01$ \\
\hline
\end{tabular}

Values are means \pm SE $(n=6)$. Mean values in each column followed by a different lower-case-letter are significantly different by Fisher's least-significant difference test (LSD) at $P \leq 0.05$.

Table 6. Effect of shading on relative water content (RWC), membrane stability index (MSI), and electrolyte leakage (EL) of cucumber transplants during the summer season.

\begin{tabular}{cccc}
\hline Treatment & RWC (\%) & MSI (\%) & EL (\%) \\
\hline & Summer cucumber (Experiment 1) & $87.90 \mathrm{~b} \pm 1.22$ \\
\hline Shade $75 \%$ & $65.56 \mathrm{a} \pm 2.62$ & $46.54 \mathrm{a} \pm 1.57$ & $87.81 \mathrm{~b} \pm 2.34$ \\
Shade 63\% & $58.41 \mathrm{ab} \pm 4.99$ & $35.69 \mathrm{~b} \pm 2.09$ & $93.56 \mathrm{a} \pm 1.08$ \\
Shade $50 \%$ & $55.55 \mathrm{~b} \pm 2.03$ & $28.86 \mathrm{c} \pm 1.93$ & $95.86 \mathrm{a} \pm 0.89$ \\
Shade $25 \%$ & $52.37 \mathrm{~b} \pm 1.39$ & $25.85 \mathrm{c} \pm 1.09$ & $91.05 \mathrm{~b} \pm 1.36$ \\
\hline & Summer cucumber (Experiment 2) & $92.93 \mathrm{ab} \pm 1.07$ \\
Shade $75 \%$ & $71.02 \mathrm{a} \pm 3.00$ & $50.86 \mathrm{a} \pm 2.49$ & $94.01 \mathrm{ab} \pm 0.81$ \\
Shade 63\% & $55.10 \mathrm{~b} \pm 3.13$ & $49.90 \mathrm{ab} \pm 1.77$ & $94.36 \mathrm{a} \pm 0.61$ \\
Shade $50 \%$ & $52.12 \mathrm{~b} \pm 3.17$ & $44.89 \mathrm{bc} \pm 2.65$ & $42.07 \mathrm{c} \pm 1.39$ \\
\hline
\end{tabular}

Values are means \pm SE $(\mathrm{n}=6)$. Mean values in each column followed by a different lower-case-letter are significantly different by Fisher's least-significant difference test (LSD) at $P \leq 0.05$. 
Table 7. Effect of shading on leaf N, P and K concentrations of cucumber transplants during the summer season.

\begin{tabular}{cccc}
\hline Treatment & N & P & K \\
\hline & Summer cucumber (Experiment 1) & \\
\hline Shade 75\% & $9.80 \mathrm{a} \pm 0.09$ & $0.16 \mathrm{a} \pm 0.01$ & $1.42 \mathrm{a} \pm 0.02$ \\
Shade 63\% & $9.05 \mathrm{~b} \pm 0.10$ & $0.10 \mathrm{~b} \pm 0.02$ & $1.27 \mathrm{~b} \pm 0.01$ \\
Shade $50 \%$ & $8.70 \mathrm{~b} \pm 0.14$ & $0.09 \mathrm{bc} \pm 0.01$ & $1.19 \mathrm{c} \pm 0.05$ \\
Shade $25 \%$ & $8.63 \mathrm{~b} \pm 0.19$ & $0.07 \mathrm{c} \pm 0.01$ & $1.04 \mathrm{~d} \pm 0.01$ \\
\hline & Summer cucumber (Experiment 2) & $1.39 \mathrm{a} \pm 0.05$ \\
\hline Shade 75\% & $9.68 \mathrm{a} \pm 0.09$ & $0.15 \mathrm{a} \pm 0.03$ & $1.22 \mathrm{ab} \pm 0.10$ \\
Shade 63\% & $9.44 \mathrm{a} \pm 0.12$ & $0.13 \mathrm{a} \pm 0.04$ & $1.15 \mathrm{~b} \pm 0.02$ \\
Shade $50 \%$ & $9.29 \mathrm{a} \pm 0.15$ & $0.10 \mathrm{~b} \pm 0.01$ & $0.91 \mathrm{c} \pm 0.04$ \\
Shade $25 \%$ & $8.49 \mathrm{~b} \pm 0.13$ & $0.07 \mathrm{c} \pm 0.02$ & \\
\hline
\end{tabular}

Values are means $\pm \mathrm{SE}(\mathrm{n}=6)$. Mean values in each column followed by a different lower-case-letter are significantly different by Fisher's least-significant difference test (LSD) at $P \leq 0.05$.
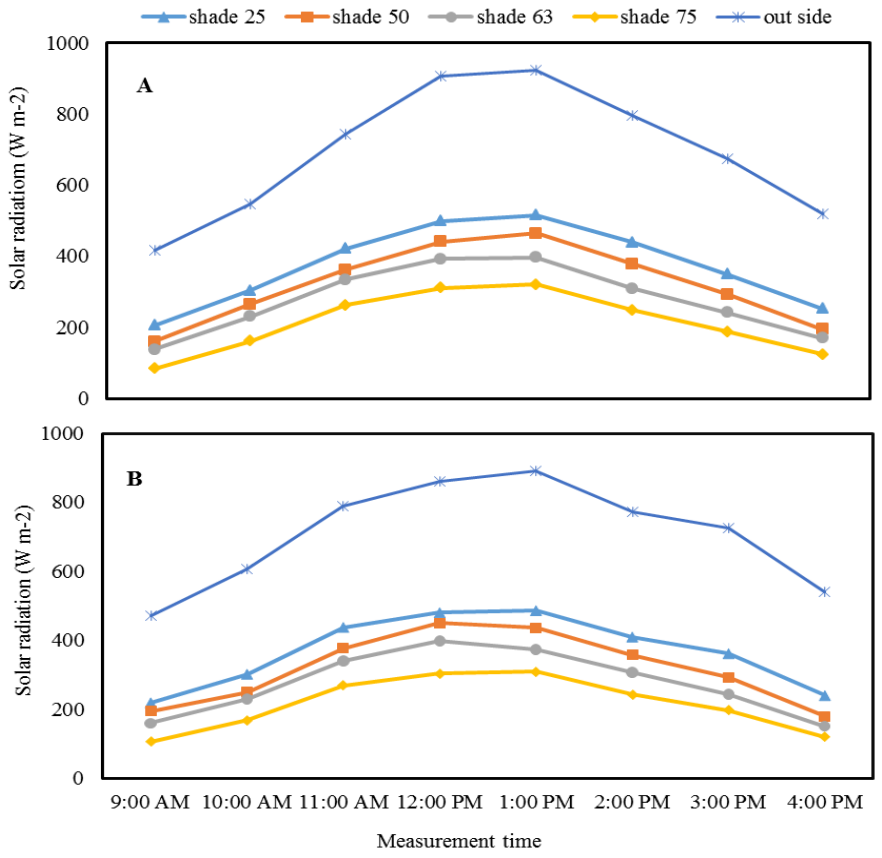

Figure 1. Solar radiation transmission for experiment 1 (A) and experiment 2 (B) under different shade levels in summer cucumber transplants between 9:00 AM and 4:00.
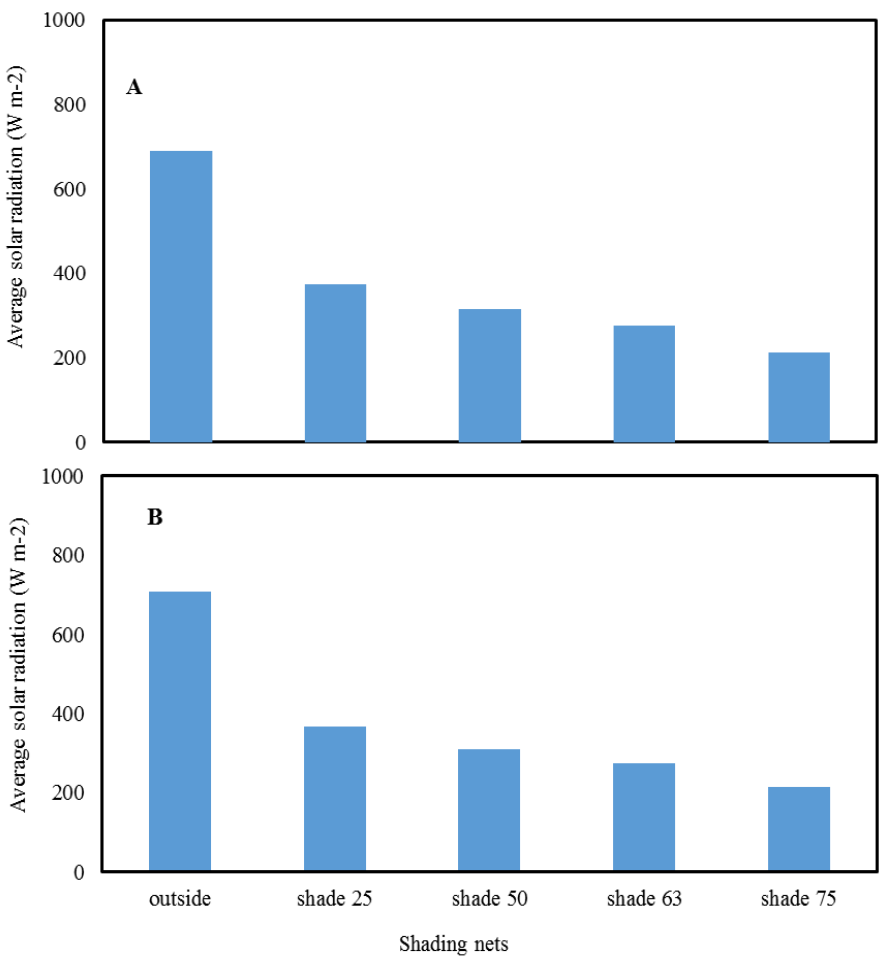

Figure 2. Average solar radiation transmission for experiment 1 (A) and experiment 2 (B) under different shade levels in summer cucumber transplants.
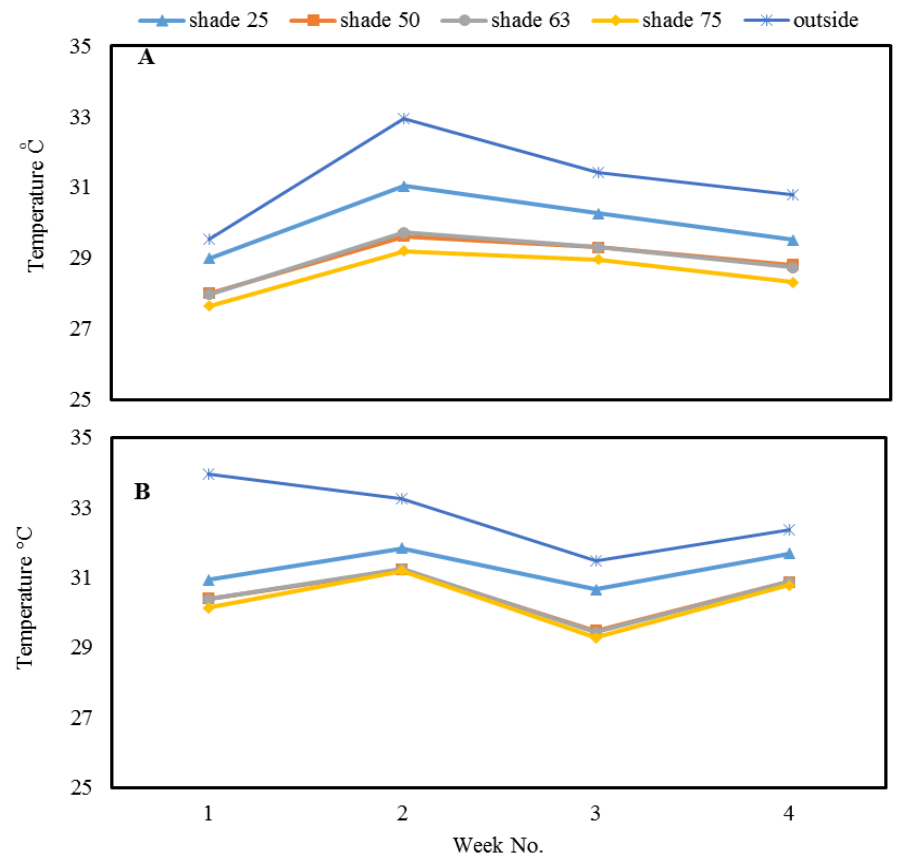

Figure 3. Weekly temperature for experiment 1 (A) and experiment 2 (B) under different shade levels in summer cucumber transplants for the duration of the experiment
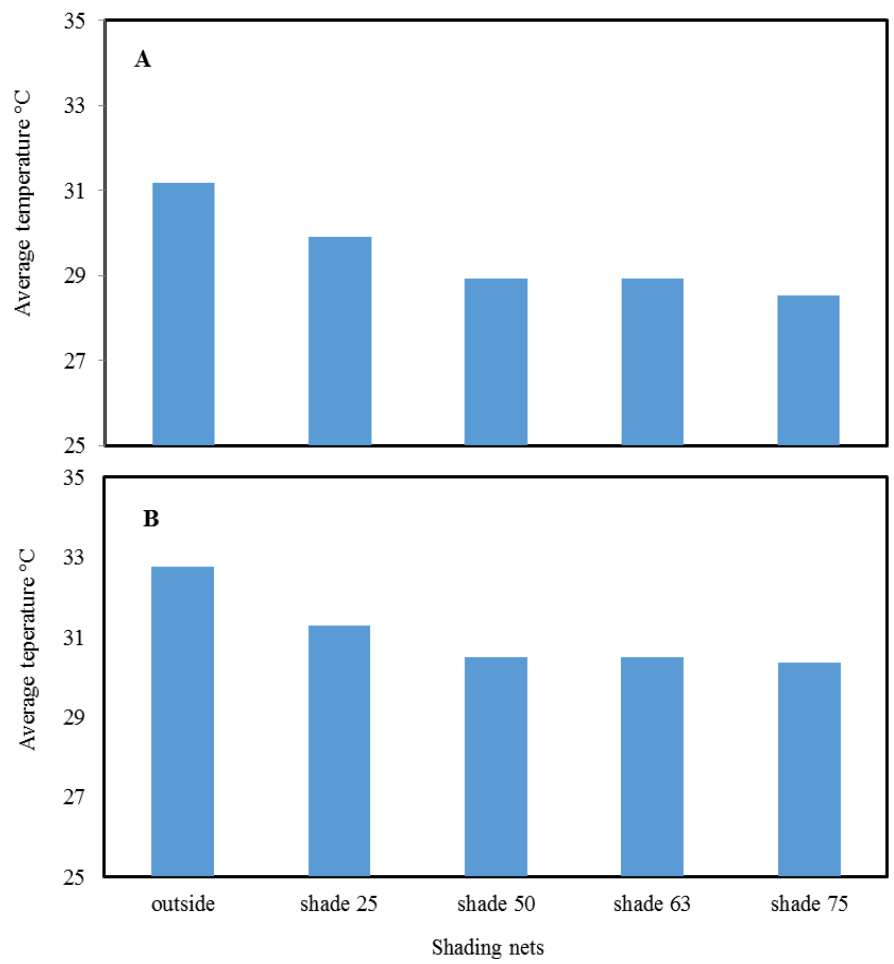

Figure 4. Average temperature for exp. 1 (A) and exp. 2 (B) under different shade levels in summer cucumber transplants. 


\section{Conclusions}

The present study concluded that solar radiation and temperature have been strongly affected by shading level. The cucumber transplants grown under higher shade levels (63 and $75 \%$ ) showed a significant increase in dehydration tolerance in terms of increased RWC and MSI and reduced EL compared to those plants grown under lower shade and/or unshaded conditions. The decreases in free proline, soluble sugars, and total free amino acids with increased shade level have been observed. This study suggests that, nets with higher shading levels (63 and/or $75 \%$ ) are a potential alternative to alleviate photo-inhibition and heat stress in cucumber transplants production.

Open Access: This is open access article distributed under the terms of the Creative Commons Attribution License, which permits unrestricted use, distribution, and reproduction in any medium, provided the original author(s) and the source are credited.

\section{REFERENCES}

Aberkani, K. Hao, X., Halleux, de D., Dorais, M., Vineberg, S. and Gosselin, A. (2010). Effects of shading using a retractable liquid foam technology on greenhouse and plant microclimates. Horttechnology, 20: 283-291.

Al-Helal, I.M. and Abdel-Ghany, A.M. (2012). Solar radiation transmission through plastic shading nets. Acta Horticultureae, 927: 731-738.

Arnon, D.I. (1949). Copper enzymes in isolated chloroplasts. Polyphenoloxidase in Beta vulgaris. Plant Physiology, 24: 1-15.

Bates, L.S., Waldren, R.P. and Teare, I. D. (1973). Rapid determination of free proline for water-stress studies. Plant and Soil, 39: 205-207.

Beneragama, C.K. and Goto, K. (2010). Chlorophyll a: b ratio increases under low-light in 'Shade-tolerant' Euglena gracilis. Tropical Agricultural Research, 22: 12-25.

Buthelezi, M.N.D., Soundy, P., Jifon, J. and Sivakumar, D. (2016). Spectral quality of photo-selective nets improves phytochemicals and aroma volatiles in coriander leaves (Coriandrum sativum L.) after postharvest storage. J. Photochemistry and. Photobiology B: Biology, 161: 328-334.

Castellano, S., Candura, A. and Scarascia Mugnozza, G. (2008). Relationship between solidity ratio, colour and shading effect of agricultural nets. Acta Horticulturae, 1: 253-258.

Chang, P.T., Hsieh, C.C. and Jiang, Y.L. (2016). Responses of 'Shih Huo Chuan' pitaya (Hylocereus polyrhizus (Weber) Britt. and Rose) to different degrees of shading nets. Scientia Horticulturae (Amsterdam), 198: 154-162.

Chang, X., Alderson, P.G. and Wright, C.J. (2008). Solar irradiance level alters the growth of basil (Ocimum basilicum L.) and its content of volatile oils. Environmental and Experimental Botany, 63: 216-223.

Clark, A.J., Landolt, W., Bucher, J.B. and Strasser, R.J. (2000). Beech (Fagus sylvatica) response to ozone exposure assessed with a chlorophyll a fluorescence performance index. Environmental Pollution, 109: 501-507.

Díaz-Pérez, J.C. (2013). Bell pepper (Capsicum annum L.) crop as affected by Shade level: Microenvironment, plant growth, leaf gas exchange and leaf mineral nutrient concentration. HortScience, 48: 175-182.

Dorais, M. and Papadopoulos, A. (2001). Greenhouse tomato fruit quality. Horticulture Review (American Society of Horticulture Science), 26: 239-319.

Dubey, R.S. and Rani, M. (1989). Influence of $\mathrm{NaCl}$ salinity on growth and metabolic status of protein and amino acids in rice seedlings. Journal of Agronomy and Crop Science, 162: 97-106.

El-Abd, M.T.G., Shanan, S.A., Abou-Hadid, A.F. and Saleh, M.M. (1994). Effect of different shading densities on growth and yield of tomato and cucumber plants. Egypt Journal of Horticulture, 21: $65-80$
Elad, Y., Messika, Y., Brand, M., David, D.R. and Sztejnberg, A. (2007). Effect of colored shade nets on pepper powdery mildew (Leveillula taurica). Phytoparasitica, 35: 285-299.

El-Gizawy, A.M., Abdallah, M.M.F., Gomaa, H.M. and Mohamed, S.S. (1992). Effect of different shading levels on tomato plants. 2. Yield and fruit quality. Acta Horticulturae, 323: 349-354.

Fu, W., Li, P. and Wu, Y. (2012). Effects of different light intensities on chlorophyll fluorescence characteristics and yield in lettuce. Scientia Horticulturae (Amsterdam), 135: 45-51.

Groninger, J.W., Seiler, J.R., Peterson, J.A. and Kreh, R.E. (1996). Growth and photosynthetic responses of four Virginia Piedmont tree species to shade. Tree Physiology, 16: 773-778.

Guillén, F. Castillo, S., Zapata, P.J., Martínez-Romero, D., Serrano, M. and Valero, D. (2007). Efficacy of 1-MCP treatment in tomato fruit. 1. Duration and concentration of 1-MCP treatment to gain an effective delay of postharvest ripening. Postharvest Biology and Technology, 43: 23-27.

Hafez, A.A. and Mikkelsen, D.S. (1981). Colorimetric determination of nitrogen for evaluating the nutritional status of rice. Communication in Soil Science and Plant Analysis, 12: 61-69.

Hayat, S., Ali, B. and Ahmad, A. (2007). In Salicylic Acid: A Plant Hormone, 1-14.

Huang, X., Xiao, X., Zhang, S., Korpelainen, H. and Li, C. (2009). Leaf morphological and physiological responses to drought and shade in two Populus cathayana populations. Biologia Planterum, 53: 588-592.

Ilić, Z.S., Milenković, L., Šunić, L. and Fallik, E. (2015). Effect of coloured shade-nets on plant leaf parameters and tomato fruit quality. Journal of the Science of Food and Agriculture, 95: 2660-2667.

Ilić, Z.S. and Fallik, E. (2017). Light quality manipulation improves vegetable quality at harvest and postharvest: A review. Environmental and Experimental Botany, 139: 79-90.

Ilic, Z.S. Milenković, L., Šunić, L., Barać, S., Mastilović, J., Kevrešan, Ž., Fallik, E. (2017). Effect of shading by coloured nets on yield and fruit quality of sweet pepper. Žemdirbystè (Agriculture), 104: 53-62.

Irigoyen, J.J., Emerich, D.W. and Sanchezdiaz, M. (1992). Waterstress induced changes in concentrations of proline and total soluble sugars in nodulated alfalfa (Medicago sativa) Plants. Plant Physiology, 84: 55-60.

Jackson, M.L. (2005). Soil chemical analysis: Advanced course. (UW-Madison Libraries Parallel Press.

Jones, P.D.D. and Briffa, K.R.R. (1992).Global surface air temperature variations during the twentieth century: Part 1 , spatial, temporal and seasonal details. The Holocene, 2: 165-179.

Kittas, C., Rigakis, N., Katsoulas, N. and Bartzanas, T. (2009).Influence of shading screens on microclimate, growth and productivity of tomato. Acta Horticultureae, 807: 97-102.

Kong, Y., Aviraham, L., Perzelan, Y. and Fallik, E. (2013). Pearl netting affects postharvest fruit quality in 'Vergasa' sweet pepper via light environment manipulation. Scientia Horticulturae (Amsterdam), 150: 290-298.

Larcher, W. (2003). Physiological plant ecology: ecophysiology and stress physiology of functional groups. (Springer Science and Business Media, 2003).

Li, S., Rajapakse, N.C., Young, R.E. and Oi, R. (2000).Growth responses of chrysanthemum and bell pepper transplants to photoselective plastic films. Scientia Horticulturae (Amsterdam), 84: 215-225.

Liu, X.Z., Kang, S.Z., Yi, H.P. and Zhang, J.H. (2003). Dry-matter partitioning, yield and leaf nutrient contents of tomato plants as influenced by shading at different growth stages. Pedosphere, 13: 263-270.

Maxwell, K. and Johnson, G. N. (2000). Chlorophyll fluorescence - a practical guide. Journal of Experinantal Botany, 51: 659-668.

Möller, M. and Assouline, S. (2007). Effects of a shading screen on microclimate and crop water requirements. Irrigation Science, 25: 171-181.

Ntsoane, L.M., Soundy, P., Jifon, J. and Sivakumar, D. (2016). Variety-specific responses of lettuce grown under the differentcoloured shade nets on phytochemical quality after postharvest 
storage. Journal of Horticulture Science and Biotechnology, 91: 520-528.

Page, A.I., Miller, R.H. and Keeny, D.R. (1982). In Part II. Chemical and Microbiological Methods, 2nd Ed. 225-246 (American Society of Agronomy, 1982).

Parker, W.C. and Mohammed, G.H. (2000). Photosynthetic acclimation of shade-grown red pine (Pinus resinosa Ait.) seedlings to a high light environment. New Forrests, 19: 1-11.

Pires, M.V., Almeida, A.A.F., Figueiredo, A.L., Gomes, F.P. and Souza, M.M. (2011). Photosynthetic characteristics of ornamental passion flowers grown under different light intensities. Photosynthetica, 49: 593-602.

Prochazkova, D., Sairam, R.K., Srivastava, G.C. and Singh, D.V. (2001). Oxidative stress and antioxidant activity as the basis of senescence in maize leaves. Plant Science, 161: 765-771.

Rady, M.M. (2011). Effect of 24-epibrassinolide on growth, yield, antioxidant system and cadmium content of bean (Phaseolus vulgaris L.) plants under salinity and cadmium stress. Scientia Horticulturae (Amsterdam), 129: 232-237.

Semida, W.M., El-Mageed, T.A.A., Mohamed, S.E. and El-Sawah, N.A. (2017). Combined effect of deficit irrigation and foliar-applied salicylic acid on physiological responses, yield, and water-use efficiency of onion plants in saline calcareous soil. Archives of Agronomy and Soil Science, 63: 1227-1239.

Semida, W.M., Hadley, P., Sobeih, W., El-Sawah, N.A. and Barakat, M.A.S. (2013). The influence of thermic plastic films on vegetative and reproductive growth of Iceberg lettuce 'Dublin'. International Journal of Agriculture Science and Engineering, 7: 593-598.

Semida, W.M. (2011). Alternative methods to enhancing the yield and quality of vegetable crops. A PhD Thesis. Fayoum University, Egypt.

Shahak, Y. (2008). Photo-Selective Netting for Improved Performance of horticultural crops. a review of ornamental and vegetable Studies Carried Out in Israel. Acta Horticultureae,
161-168.

Shahak, Y., Ratner, K., Giller, Y.E., Zur, N., Or, E., Gussakovsky, E.E., Stern, R., Sarig, P., Raban, E., Harcavi, E., Doron, I. and Greenblat-Avron, Y. (2008). Improving solar energy utilization, productivity and fruit quality in orchards and vineyards by photoselective netting. Acta Horticultureae, 772: 65-72.

Shinohara, T. and Leskovar, D.I. (2014). Effects of ABA, antitranspirants, heat and drought stress on plant growth, physiology and water status of artichoke transplants. Scientia Horticulturae (Amsterdam), 165: 225-234.

Sinclair, T.R. and Ludlow, M.M. (1986). Influence of soil water supply on the plant water balance of four tropical grain legumes. Australian Journal of Plant Physiology, 13: 329-341.

Sivakumar, D., Jifon, J. and Soundy, P. (2017). Spectral quality of photo-selective shade nettings improves antioxidants and overall quality in selected fresh produce after postharvest storage. Food Reviews International, 1-18.

Spoustová, P., Synková, H., Valcke, R. and Čevrovská, N. (2013). Chlorophyll a fluorescence as a tool for a study of the Potato virus $\mathrm{Y}$ effects on photosynthesis of nontransgenic and transgenic Pssu-ipt tobacco. Photosynthetica, 51: 191-201.

Stamps, R.H. (2009).Use of colored shade netting in horticulture. HortScience, 44: 239-241.

Sullivan, C.Y. and Ross, W.M. (1979). In Mussel, H., Staples, R.C. (Eds.), Stress Physiology in Crop Plants 263-281 (John Wiley and Sons, New York, USA.

Taiz, L. and Zeiger, E. (2010). Plant Physiology. Annals of Botany.

Tinyane, P.P. (2013). Influence of photo-selective netting on plant morphology, fruit quality and bioactive compounds in tomato cultivars. (A MSc thesis, Faculty of Science, Tshwane University of Technology, Pretoria.

Wallace, D.H. and Munger, H.M. (1965). Studies of the physiological basis for yield differences. I. Growth Analysis of Six Dry Bean Varieties. Crop Science, 5: 343-348. 